\title{
Rate of Gain and Utilization of Feed as Affected by Different Levels of Coconut Meal in Starting, Growing, and Fattening Diets for Birds of a Broiler Stock and Laying Strains
}

\author{
Manuel Soldevila, Manuel Rojas-Daporta, and Ismael Carlo ${ }^{2}$
}

\section{INTRODUCTION}

Coconut meal is a by-product of coconut oil extraction by the expeller process. The production of coconut meal in Puerto Rico at present is not high. There is a possibility, however, that large quantities of this by-product may become available for use in animal diets in the future.

Thomas and Scott $(10)^{2}$ reported that properly supplemented starting diets for chickens containing 40-percent copra meal promoted good growth and feed conversion rates. They also disproved the theory that copra meal contains toxic factors. Fronda et al. (4) reported solvent-extracted copra meal as superior to expeller-process meals because lysine is less severely damaged.

It is well established that coconut proteins contain low levels of lysine. Momoñgan et al. (5) reported that both lysine and methionine are the limiting amino acids in broiler rations containing high levels of copra meal. Castillo et al. (3) reported that over 15-percent copra meal in broiler diets considerably depressed both rate of growth and feed utilization.

The objectives of this study were to determine maximum and optimum levels of coconut meal to use in starting, fattening, and growing diets for birds of a broiler and laying strain.

\section{MATERIALS AND METHODS}

Seven studies were conducted during the starting, growing and fattening periods using birds of a broiler and of laying strains.

\section{CHICKS OF A BROILER STRAIN}

Two studies (A and B) were completed during the starting period. The day-old birds were housed in a barn located at the Main Station.

In study $A$, three levels of coconut meal $(0,25$, and 50 percent) were com-

1 Associate Nutritionist and Associate Professor, Agricultural Experiment Station; Rio Piedras, Puerto Rico; Animal Husbandman, Lajas Substation; and Animal Husbandman and Professor, Lajas Substation, Mayagüez Campus, University of Puerto Rico, Mayagüez, P.R.

Italic numbers in parentheses refer to Literature Cited, pp. 540. 
pared simultaneously in two series (Parts I and II). conducted from March to May 1967 using a balanced incomplete block design replicated four times. Part A-I contained isocaloric-isonitrogenous diets 1, 2 and 3, while Part A-II contained isocaloric non-isonitrogenous diets 1, 4, and 5 (table 1).

In study $B$, conducted from January to February 1968, eight levels of coconut meal $(0,7,14,21,28,35,42$, and 50 percent) were evaluated in isocaloric isonitrogenous diets using a partially balanced incomplete block design with four 24-bird replicates of the eight treatments. Percent protein increased with each successive substitution of yellow corn by coconut meal, since the content of protein sources (tuna and soybean meals) was maintained constant. Each replicate was housed in a 3.6 X $1.8 \mathrm{~m}$. floor pen. Heat was provided during the first 2 weeks of age. The basal diet used is described in table 1.

Studies C, D and E, (basal diets outlined in table 1) were completed with Vantress strain birds at the Main Station during the fattening period.

In study C, conducted from March 2 to 16,1967 , three levels of coconut meal $(0,25$, and 50 percent) were compared in two concurrent evaluations using a random block design with three replicates of the three treatments. In study C-Part I the diets were isocaloric and isonitrogenous, while in study C-Part II, they were isocaloric non isonitrogenous. Each 19-bird group was housed in a $3.6 \times 1.8 \mathrm{~m}$. floor pen.

In study D, conducted from May 5 to 18, 1967, four levels of coconut meal $(0,25,50$, and 75 percent) were evaluated in non-isonitrogenous nonisocaloric diets using a random block design with four replications of the four treatments. Each ten-bird replicate was housed in a 3.6 X $1.8 \mathrm{~m}$. floor pen.

In study $E$, conducted on March 1968, eight levels (0, 7, 14, 21, 28, 35; 42 , and 50 percent) of coconut meal were evaluated in isocaloric-isonitrogenous diets using a partially balanced incomplete block design with four replicates of the eight treatments. This study was a continuation of starting study B.

\section{CHICKS OF LAYING STRAINS}

Studies $\mathrm{F}$ and $\mathrm{G}$ were completed during the growing period.

In study F, conducted from December 1 to 16,1966 (6 to 12 weeks old), the birds were housed in floor pens $4.5 \times 2.3 \mathrm{~m}$. in a barn located at the Mayagüez (Alzamora) College Farm. Four levels of coconut meal (0.0, $18.5,55.5$, and 74.2 percent) were evaluated using a balanced incomplete block design with three replications of the four treatments. Groups of 10 birds each (2 each Hyline, Kimble, Shaver, Garber and Cameron) were used. Diets were non-isocaloric, non-isonitrogenous (table 1). 
TABLE 1.-Basal diets used during the starting and fattening periods of broiler stock, and the growing period of laying stock

\begin{tabular}{|c|c|c|c|c|}
\hline \multicolumn{5}{|c|}{ Broiler stock } \\
\hline Ingredients and composition & Starting A & Starting B & Fattening C & $\begin{array}{c}\text { Fattening } \\
\mathbf{D} \text { and } \mathrm{E}\end{array}$ \\
\hline \begin{tabular}{l}
\multicolumn{1}{c}{ Ingredients } \\
Corn, Dent No. 2, ground \\
Coconut meal 1 \\
Soybean meal \\
Tuna fishmeal \\
Skimmed milk, dried \\
Dicalcium phosphate \\
Animal grease, stabilized \\
NaCl \\
Premix \\
Crude protein, analyzed \\
Calcium, analyzed \\
Phosphorus, analyzed \\
Calories, calculated
\end{tabular} & $\begin{array}{r}\text { Percent } \\
71.2 \\
.0 \\
13.0 \\
13.0 \\
2.0 \\
.0 \\
.0 \\
.5 \\
.3^{2} \\
\\
20.31 \\
1.11 \\
.80 \\
1002\end{array}$ & $\begin{array}{r}\text { Percent } \\
63.2 \\
.0 \\
20.0 \\
11.0 \\
2.0 \\
.0 \\
3.0 \\
.5 \\
.3^{2} \\
20.75 \\
1.12 \\
.88 \\
1078\end{array}$ & $\begin{array}{r}\text { Percent } \\
75.0 \\
.0 \\
9.6 \\
9.6 \\
.0 \\
1.0 \\
4.0 \\
.5 \\
.3^{8} \\
16.23 \\
1.07 \\
.83\end{array}$ & $\begin{array}{r}\text { Percent } \\
79.6 \\
.0 \\
10.0 \\
9.6 \\
.0 \\
.0 \\
.0 \\
.5 \\
.0 \\
3^{8}\end{array}$ \\
\hline
\end{tabular}

Laying stock

\begin{tabular}{l|r|c}
\hline \multicolumn{1}{c|}{ Ingredients and composition } & Growing F & Growing G \\
\hline \multicolumn{1}{c}{ Ingredients } & Percent & Percent \\
Corn, Dent No. 2, ground & 74.2 & 79.6 \\
Coconut meal & .0 & .0 \\
Soybean meal & 12.0 & 9.3 \\
Tuna fishmeal & 12.0 & 9.3 \\
Dicalcium phosphate & 1.0 & 1.0 \\
Animal grease, stabilized & .0 & .0 \\
NaCl & .5 & .5 \\
Premix $\quad .3$ & .3 \\
& 18.54 & 16.30 \\
Crude protein, analyzed & 1.27 & 1.05 \\
Calcium, analyzed & .95 & .83 \\
Phosphorus, analyzed & 1017 & 1033 \\
Calories, calculated & .3 & \\
\hline
\end{tabular}

1 The average percentage in the chemical composition of the coconut meal used was: moisture 14.03; crude protein 22.07; fat 12.39; fiber 8.32; ash 6.80 (0.26 Ca and $0.84 \mathrm{P}$ ); and nitrogen free extract 36.39 . This analysis was conducted following the methods described by the Association of Official Agricultural Chemists (1).

2 Contains 0.0006 vitamins $\mathrm{A} / \mathrm{D}_{2}(500,000 / 100,000 \mathrm{IU} / \mathrm{g}$.); 0.0004 riboflavin; 0.1000 choline chloride (25 percent); 0.0008 niacin; 0.0004 calcium pantothenate; 0.0750 coccidiostat; 0.0250 manganese sulfate (75 percent); 0.0850 terramycin (12 g. oxytetracycline $+4 \mathrm{mg}$. vitamin $B_{12} / \mathrm{kg}$.).

3 Contains 0.0006 vitamins $\mathrm{A} / \mathrm{D}_{2}(500,000 / 100,000 \mathrm{IU} / \mathrm{g}$.); 0.0008 riboflavin; 0.1000 choline chloride (25 percent); 0.0008 calcium pantothenate; 0.0250 manganese sulfate (75 percent); 0.2000 terramycin ( $3 \mathrm{~g}$. oxytetracycline $+3 \mathrm{mg}$. viamin $B_{12} / \mathrm{kg}$.).

- Based on values obtained in our Laboratory $(\theta)$ and those tabulated by the $\mathrm{Na}$ tional Research Council (6). 
In study $\mathrm{G}$, conducted from March 15 to April 19, 1967 (10 to 14 weeks old), the birds were housed in floor pens $3.6 \mathrm{X} 1.8 \mathrm{~m}$. in a barn located at the Rio Piedras Main Station. Three levels of coconut meal $(0,25$ and 50 percent) were evaluated in two simultaneous studies, using a random block design with three replicates of the three treatments, each of twelve Dekalb birds. In study G-Part I, the diets were isonitrogenous isocaloric; in study G-Part II, they were non-isonitrogenous isocaloric. The basal diets used in both experiments are described in table 1.

In all studies the feed and water were offered ad libitum. Net liveweight gain and utilization of feed were the comparison criteria. The statistical evaluation of the data was based on the methods of Bose et al. (2), Snedecor (8) and Zelem (11), using a program developed for Computer IBM 1620.

\section{RESULTS AND DISCUSSION}

\section{CHICKS OF A BROILER STRAIN}

The data from studies A and B conducted during the starting period are shown in table 2. In study A-Part I, both the rate of gain and of utilization of feed decreased considerably with increases in the level of coconut meal from 0 to 25 or 50 percent of the diet, while the level of crude protein was maintained constant (study A-Part I, diets 1, 2 and 3, respectively).

In study A-Part II, the birds that received diet 4, containing 25-percent coconut meal in pound for pound substitution of yellow corn, gained better and more efficiently than those on the control diet 1 . The birds on diet 5 , containing a 50-percent level of coconut meal, gained less weight and had a poorer feed conversion than those on the control diet or on the intermediate level diet 4.

The data from study A seems to indicate that birds which received additional amounts of the essential amino acids lysine and methionine-cystine provided in diets 4 and 5 had a better overall performance than those on diets 2 and 3, in which the methionine-cystine and particularly the lysine contents were considerably lower than the National Research Council minimal requirements (7).

In study B, growth performance of birds that received isocaloric diets equivalent and sufficient amounts of methionine-cystine decreased with increases of coconut meal between the 21- and 28-percent level (fig. 1), even though the total lysine content increased progressively (table 2). This may be explained as due to the availability of lysine in the expeller process coconut meal incorporated in the diet (4). Our data indicates that the lysine content in the experimental diets of study B, as calculated from a chemical analysis of tuna fishmeal in our laboratory, as indicated by unpublished data from commercial tuna processing plants (9), and from values tabulated 
by the National Research Council (6) for corn, soybean, and coconut meals, surpasses the minimum requirements ( 7$)$. It is speculated, therefore, that perhaps only a small proportion of the lysine is available to the birds.

TABLE 2.-Rate of gain, utilization of feed, and comparative feed costs of diets used during the starting period with broilers

\begin{tabular}{|c|c|c|c|c|c|c|c|}
\hline $\begin{array}{c}\text { Diet } \\
\text { number }\end{array}$ & $\begin{array}{l}\text { Percent } \\
\text { coconut- } \\
\text { protein }\end{array}$ & $\begin{array}{c}\text { Percent } \\
\text { lysine }\end{array}$ & $\begin{array}{c}\text { Percent } \\
\text { methionine- } \\
\text { cystine }^{1}\end{array}$ & $\begin{array}{c}\text { Mean net } \\
\text { gain²-grams }\end{array}$ & $\begin{array}{l}\text { Average cost// } \\
\text { pound of } \\
\text { feed }{ }^{2}-\text { cents }\end{array}$ & $\begin{array}{c}\text { Mean } \\
\text { efficiency } \\
\text { feed/gain } \\
\text { ratio }\end{array}$ & $\begin{array}{c}\text { Feed cost/ } \\
\text { pound } \\
\text { produced } \\
\text { cents }\end{array}$ \\
\hline \multicolumn{8}{|c|}{ Study $A-$ Part I } \\
\hline $\begin{array}{l}\mathbf{1} \\
\mathbf{2} \\
\mathbf{3}\end{array}$ & $\begin{array}{r}0-20.0 \\
25-20.0 \\
50-20.0\end{array}$ & $\begin{array}{l}1.00 \\
0.89 \\
0.78\end{array}$ & $\begin{array}{r}0.69 \\
.61 \\
.60\end{array}$ & $\begin{array}{l}754 \text { a } \\
686 \mathrm{~b} \\
572 \mathrm{c}\end{array}$ & $\begin{array}{l}5.48 \\
5.03 \\
4.56\end{array}$ & $\begin{array}{l}1.84 \mathrm{a} \\
1.96 \mathrm{a} \\
2.19 \mathrm{~b}\end{array}$ & $\begin{array}{r}10.08 \\
9.86 \\
9.99\end{array}$ \\
\hline \multicolumn{8}{|c|}{ Study A-Part II } \\
\hline $\begin{array}{l}1 \\
4 \\
5\end{array}$ & $\begin{array}{r}\dot{0}-20.0 \\
25-22.5 \\
50-25.0\end{array}$ & $\begin{array}{l}1.00 \\
1.08 \\
1.15\end{array}$ & $\begin{array}{r}0.69 \\
.73 \\
.83\end{array}$ & $\begin{array}{l}754 \mathrm{a} \\
763 \mathrm{a} \\
654 \mathrm{~b}\end{array}$ & $\begin{array}{l}5.48 \\
5.16 \\
4.84\end{array}$ & $\begin{array}{l}1.84 \mathrm{a} \\
1.76 \mathrm{a} \\
2.09 \mathrm{~b}\end{array}$ & $\begin{array}{r}10.08 \\
9.08 \\
10.12\end{array}$ \\
\hline \multicolumn{8}{|c|}{ Study B } \\
\hline $\begin{array}{r}6 \\
7 \\
8 \\
9 \\
10 \\
11 \\
12 \\
13\end{array}$ & $\begin{array}{r}0-20.0 \\
7-20.0 \\
14-20.0 \\
21-20.0 \\
28-20.0 \\
35-20.0 \\
42-20.0 \\
50-20.0\end{array}$ & $\begin{array}{l}1.12 \\
1.14 \\
1.15 \\
1.17 \\
1.18 \\
1.21 \\
1.22 \\
1.24\end{array}$ & $\begin{array}{r}0.71 \\
.72 \\
.72 \\
.73 \\
.73 \\
.73 \\
.73 \\
.74\end{array}$ & $\begin{array}{l}706 \mathrm{a} \\
684 \mathrm{ab} \\
702 \mathrm{a} \\
711 \mathrm{a} \\
655 \mathrm{bc} \\
631 \mathrm{~cd} \\
608 \mathrm{~d} \\
561 \mathrm{e}\end{array}$ & $\begin{array}{l}\mathbf{5 . 6 6} \\
\mathbf{5 . 6 2} \\
\mathbf{5 . 5 8} \\
\mathbf{5 . 5 5} \\
\mathbf{5 . 5 1} \\
\mathbf{5 . 4 7} \\
\mathbf{5 . 4 3} \\
\mathbf{5 . 4 0}\end{array}$ & $\begin{array}{l}2.01 \mathrm{a} \\
2.08 \mathrm{ab} \\
2.05 \mathrm{a} \\
2.01 \mathrm{a} \\
2.14 \mathrm{ab} \\
2.02 \mathrm{a} \\
2.21 \mathrm{~b} \\
2.21 \mathrm{~b}\end{array}$ & $\begin{array}{l}11.38 \\
11.69 \\
11.44 \\
11.16 \\
11.79 \\
11.05 \\
12.00 \\
11.93\end{array}$ \\
\hline
\end{tabular}

1 Calculated from National Research Council data (6), unpublished data from commercial tuna-processing plants, and from our laboratory $(\theta)$. The minimum requirements set by the National Research Council ( 8 ) for lysine and methioninecystine are 1.10 and 0.75 percent of the diet, respectively.

2 Means followed by the same letter do not differ significantly $(P<.05)$.

Based on values calculated using average prices paid by the Agricultural Experiment Station during 1967 for the ingredients used in preparing all diets, plus $\$ 0.60$ for mixing and handling costs.

- Obtained by multiplying the efficiencies by the values described under average cost/pound of feed.

The average growth rates of birds receiving diets containing 28- to 50 percent coconut meal were increasingly inferior to that of the control. Feed utilization efficiency was comparable for all the groups except for those 
receiving the 42- and 50 percent levels of coconut meal (fig. 2). These results verify in part the conclusions of Thomas (10) that high levels of coconut meal may be used in properly balanced diets.

The fattening-period data of studies C, D and E are described in tables 3 and 4.

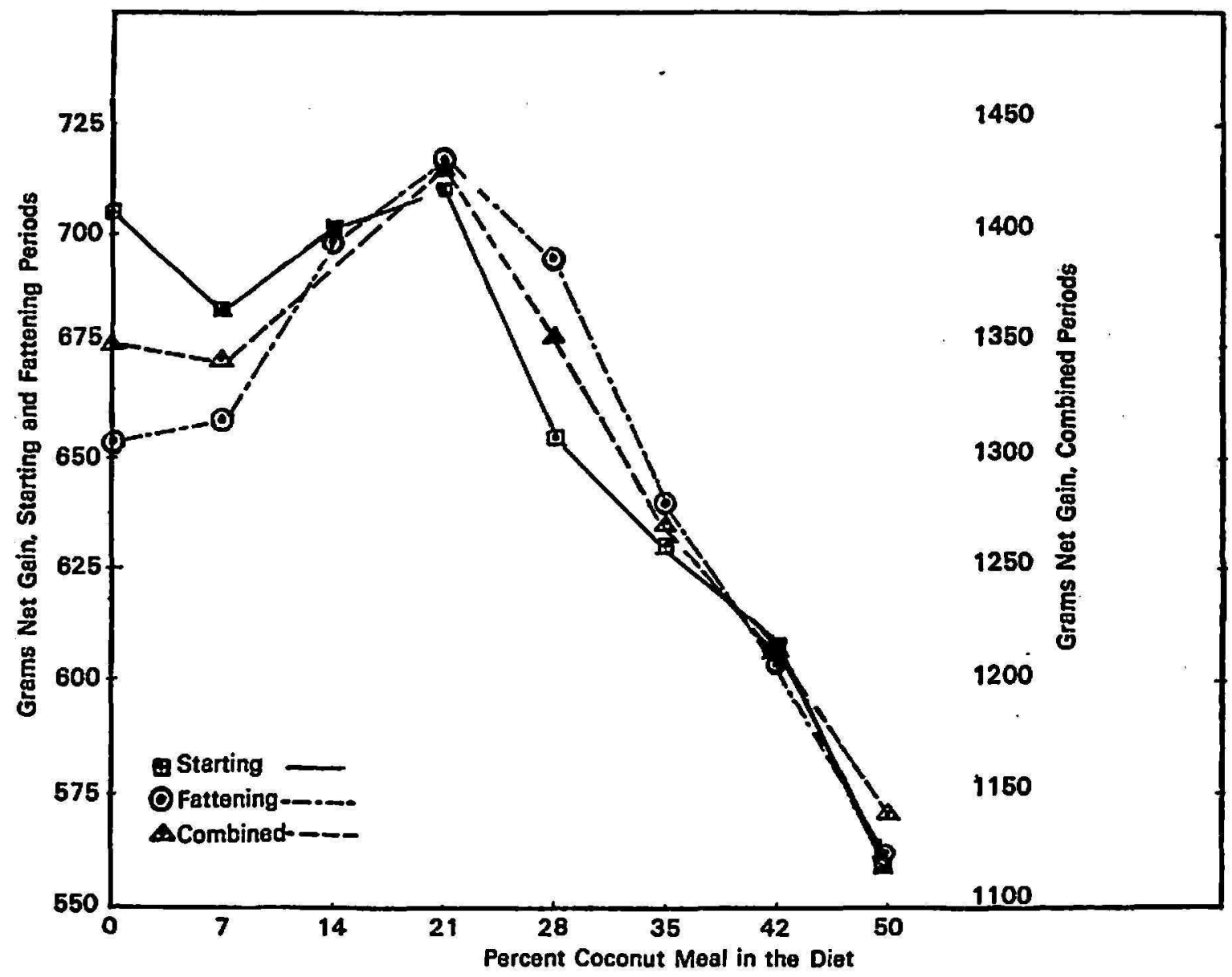

Fra. 1.-Net gain from the different diets used in starting study $B$, in fattening study $\mathbf{E}$, and the combined periods in studies $\mathbf{B}$ and $\mathbf{E}$.

In study C-Part I, the increment of coconut meal content in isocaloric diets 14, 15, and 16 containing adequate amounts of methionine-cystine caused a stepwise decrease in feed efficiency and a decrease in growth rate in the diet containing 50-percent coconut meal. This may be explained as due to the suboptimal content of lysine in diet 16 and a marginal level in diet 15 .

In study C-Part II, with isocaloric diets in which the protein levels were increasingly higher and provided with enough methionine-cystine and lysine, the birds on both the 25- and the 50-percent levels, diets 17 and 18, respectively, had a better growth response and an equivalent efficiency of 
feed utilization when compared to control diet 14. These results follow the general trend discussed above when isocaloric non-isonitrogenous diets were used for broilers during the starting period (table 2).

In study $\mathrm{D}$, in which non-isonitrogenous, non-isocaloric diets were compared, the overall performance of the birds decreased progressively with corresponding increases of coconut meal levels. These differences are assumed to be due mainly to caloric deficiencies resulting from unit-per-unit

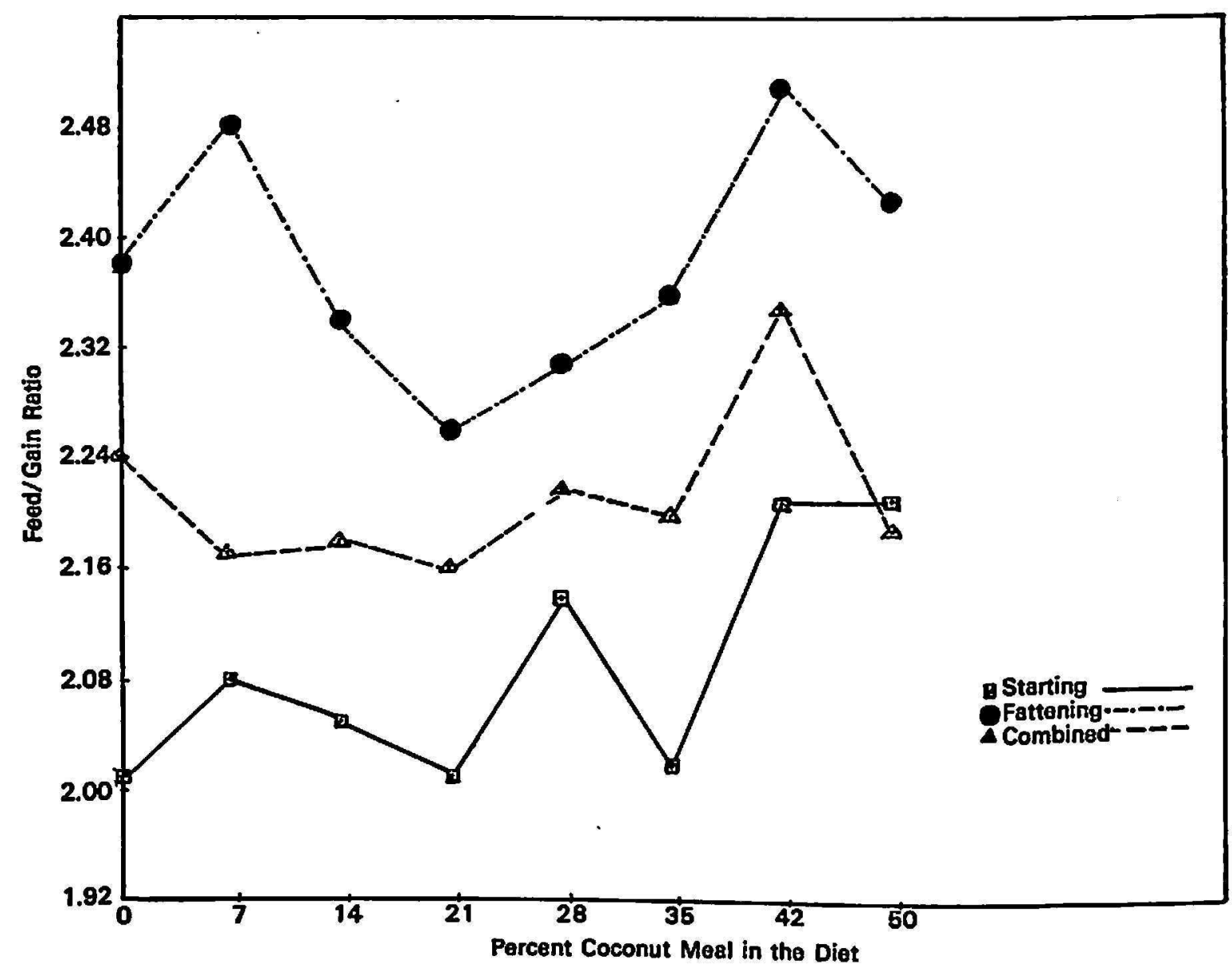

Fra. 2. -Efficiency of utilization of the different diets used in starting study $B$, in fattening study $\mathbf{E}$, and the combined periods in studies $\mathbf{B}$ and $\mathbf{E}$.

substitution of yellow corn ( 1,100 calories) with coconut meal ( 600 calories), because both methionine-cystine and lysine increased with increments of coconut meal and appeared adequate.

In study $\mathrm{E}$, where isocaloric non-isonitrogenous diets containing suffcient amounts of methionine-cystine were compared, a satisfactory rate of gain was obtained with diets containing levels of coconut meal as high as 28 percent (fig. 1). The explanation of the poor availability of lysine given in the discussion under study B, seems to offer the best explanation under the circumstances. Efficiency of utilization was not statistically different 
for all groups, including the highest level used, 50-percent coconut meal (fig. 2).

Evaluation of the combined data follows a similar trend in the component studies $B$ and $E$ (figs. 1 and 2). Efficiency of feed utilization was about the same for all groups. The growth rate was comparable in the diets using

TABLE 3.-Rate of gain, utilization of feed, and comparative feed costs of the diets used during the fattening period of broilers

\begin{tabular}{|c|c|c|c|c|c|c|c|}
\hline $\begin{array}{c}\text { Diet } \\
\text { number }\end{array}$ & $\begin{array}{l}\text { Percent } \\
\text { coconut- } \\
\text { protein }\end{array}$ & $\begin{array}{l}\text { Percent } \\
\text { lysinet }\end{array}$ & $\begin{array}{c}\text { Percent } \\
\text { methionine- } \\
\text { cystine? }\end{array}$ & $\begin{array}{c}\text { Mean net } \\
\text { gain²-grams }\end{array}$ & $\begin{array}{c}\text { Average cost/ } \\
\text { pound of } \\
\text { feed } 2 \text { of-ents }\end{array}$ & $\begin{array}{c}\text { Mean } \\
\text { efficiencye } \\
\text { feed/gain } \\
\text { ratio }\end{array}$ & $\begin{array}{l}\text { Feed cost/ } \\
\text { pound } \\
\text { producedi } \\
\text { cents }\end{array}$ \\
\hline \multicolumn{8}{|c|}{ Study C-Part I } \\
\hline $\begin{array}{l}14 \\
15 \\
16\end{array}$ & $\begin{array}{r}0-16 \\
25-16 \\
50-16\end{array}$ & $\begin{array}{r}0.75 \\
.64 \\
.41\end{array}$ & $\begin{array}{r}0.56 \\
.53 \\
.47\end{array}$ & $\begin{array}{l}522 \text { a } \\
504 \text { a } \\
322 \text { b }\end{array}$ & $\begin{array}{l}4.93 \\
4.49 \\
4.02\end{array}$ & $\begin{array}{l}2.37 \mathrm{a} \\
2.49 \mathrm{~b} \\
3.56 \mathrm{c}\end{array}$ & $\begin{array}{l}11.68 \\
11.18 \\
14.31\end{array}$ \\
\hline \multicolumn{8}{|c|}{ Study C-Part II } \\
\hline $\begin{array}{l}14 \\
17 \\
18\end{array}$ & $\begin{array}{r}0-16 \\
25-19 \\
50-22\end{array}$ & $\begin{array}{r}0.75 \\
.83 \\
.90\end{array}$ & $\begin{array}{r}0.56 \\
.61 \\
.64\end{array}$ & $\begin{array}{l}522 \text { a } \\
540 \text { a } \\
536 \text { a }\end{array}$ & $\begin{array}{l}4.93 \\
4.62 \\
4.30\end{array}$ & $\begin{array}{l}2.37 \mathrm{a} \\
2.34 \mathrm{a} \\
2.30 \mathrm{a}\end{array}$ & $\begin{array}{r}11.68 \\
10.81 \\
9.89\end{array}$ \\
\hline \multicolumn{8}{|c|}{ Study $D$} \\
\hline $\begin{array}{l}19 \\
20 \\
21 \\
22\end{array}$ & $\begin{array}{r}0-16 \\
25-19 \\
50-22 \\
75-25\end{array}$ & $\begin{array}{r}0.75 \\
.83 \\
.90 \\
.98\end{array}$ & $\begin{array}{r}0.56 \\
.61 \\
.64 \\
.68\end{array}$ & $\begin{array}{l}663 a \\
622 a \\
613 a \\
572 a\end{array}$ & $\begin{array}{l}5.06 \\
4.74 \\
4.42 \\
4.10\end{array}$ & $\begin{array}{l}2.58 \mathrm{a} \\
2.75 \mathrm{ab} \\
2.85 \mathrm{~b} \\
3.20 \mathrm{c}\end{array}$ & $\begin{array}{l}13.05 \\
13.04 \\
12.60 \\
13.12\end{array}$ \\
\hline
\end{tabular}

${ }^{1}$ Calculated as in 1 table 2 . The minimum requirements set by the National Research Council ( 8 ) for lysine and methionine-cystine are 0.5 percent of the diet, respectively.

$2,8,4$ See $2,2,4$ table 2.

levels as high as 28-percent coconut meal. Higher levels caused a decrease in weight gain of the birds.

\section{CHICKS OF LAYING STRAINS}

The results from studies $\mathrm{F}$ and $\mathrm{G}$ conducted during the growing period are shown in table 5 . In study $\mathrm{F}$, in which non-isonitrogenous, non-isocaloric diets containing an adequate amount of methionine-cystine and lysine were used, the gain was similar for all groups, while efficiency decreased as the level of coconut meal increased.

The results from study G-Part I, in which constant levels of crude 
protein and adequate amounts of methionine-cystine were used, demonstrate that both the rates of gain and of feed utilization considerably diminished as the level of coconut meal increased. This may be explained as due to the marginal levels of methionine-cystine and deficient levels of available lysine present.

TABLE 4.-Rate of gain, utilization of feed, and comparative feed costs of the different diets used in fattening study $E$ and the combined data from studies $B$ and $E$

\begin{tabular}{c|c|c|c|c|c|c|c}
\hline $\begin{array}{c}\text { Diet } \\
\text { number }\end{array}$ & $\begin{array}{c}\text { Percent } \\
\text { coconut- } \\
\text { protein }\end{array}$ & Percent \\
lysinel & $\begin{array}{c}\text { Percent } \\
\text { methionine- } \\
\text { cystinel }\end{array}$ & $\begin{array}{c}\text { Mean net } \\
\text { gain2 } \\
\text { grams }\end{array}$ & $\begin{array}{c}\text { Average } \\
\text { cost/pound } \\
\text { of feed² } \\
\text { cents }\end{array}$ & $\begin{array}{c}\text { Mean } \\
\text { efficiency } \\
\text { feed/gain } \\
\text { ratio }\end{array}$ & $\begin{array}{c}\text { Feed } \\
\text { cost// } \\
\text { pound } \\
\text { produced/2 } \\
\text { cents }\end{array}$ \\
\hline
\end{tabular}

Faltening-Study $E$

\begin{tabular}{l|r|r|r|l|l|l|l}
\hline 23 & $0-16$ & 0.78 & 0.59 & $654 \mathrm{bc}$ & 4.95 & $2.38 \mathrm{a}$ & 11.73 \\
24 & $7-16$ & .80 & .59 & $658 \mathrm{ab}$ & 4.90 & $2.48 \mathrm{a}$ & 11.91 \\
25 & $14-16$ & .82 & .60 & $699 \mathrm{ab}$ & 4.86 & $2.34 \mathrm{a}$ & 11.37 \\
26 & $21-16$ & .84 & .60 & $717 \mathrm{a}$ & 4.81 & $2.26 \mathrm{a}$ & 10.87 \\
27 & $28-16$ & .87 & .61 & $695 \mathrm{ab}$ & 4.76 & $2.31 \mathrm{a}$ & 11.04 \\
28 & $35-16$ & .89 & .61 & $640 \mathrm{bc}$ & 4.71 & $2.36 \mathrm{a}$ & 11.07 \\
29 & $42-16$ & .91 & .62 & $604 \mathrm{~cd}$ & 4.67 & $2.51 \mathrm{a}$ & 11.58 \\
30 & $50-16$ & .93 & .63 & $563 \mathrm{~d}$ & 4.62 & $2.43 \mathrm{a}$ & 11.18 \\
\hline
\end{tabular}

Combined periods-Sludies $B$ and $E$

\begin{tabular}{r|c|l|c|l|l|l|l}
\hline $6 / 23^{5}$ & $0-20 / 16^{5}$ & $1.12 / .78^{5}$ & $0.71 / .59^{5}$ & $1352 \mathrm{ab}$ & 10.32 & $2.24 \mathrm{a}$ & 23.11 \\
$7 / 24$ & $7-20 / 16$ & $1.14 / .80$ & $.72 / .59$ & $1346 \mathrm{ab}$ & 10.54 & $2.17 \mathrm{a}$ & 23.60 \\
$8 / 25$ & $14-20 / 16$ & $1.15 / .82$ & $.72 / .60$ & $1401 \mathrm{a}$ & 10.32 & $2.18 \mathrm{a}$ & 22.81 \\
$9 / 26$ & $21-20 / 16$ & $1.17 / .84$ & $.73 / .60$ & $1431 \mathrm{a}$ & 10.25 & $2.16 \mathrm{a}$ & 22.03 \\
$10 / 27$ & $28-20 / 16$ & $1.18 / .87$ & $.73 / .61$ & $1356 \mathrm{ab}$ & 10.33 & $2.22 \mathrm{a}$ & 22.83 \\
$11 / 28$ & $35-20 / 16$ & $1.21 / .89$ & $.73 / .61$ & $1271 \mathrm{bc}$ & 10.05 & $2.20 \mathrm{a}$ & 22.12 \\
$12 / 29$ & $42-20 / 16$ & $1.22 / .91$ & $.73 / .62$ & $1215 \mathrm{~cd}$ & 10.08 & $2.35 \mathrm{~b}$ & 23.58 \\
$13 / 30$ & $50-20 / 16$ & $1.24 / .93$ & $.74 / .63$ & $1143 \mathrm{~d}$ & 10.50 & $2.19 \mathrm{a}$ & 23.11 \\
\hline
\end{tabular}

1 See 1 table 3.

2,8,4 See $2,8,4$ table 2.

Starting/fattening.

When 20-percent crude protein coconut meal substituted 9-percent crude-protein yellow corn, pound for pound, in study G-Part II, the group receiving the 25-percent level (diet 38 ) gained faster and used the feed more efficiently than the control group (diet 35). The group using diet 39 containing 50 percent had a growth rate equal to that for the control group but a slightly poorer feed utilization.

When the same levels of coconut meal were compared in diets with 
optimum caloric content ( 36 vs. 38 , and 37 vs. 39 ) it became apparent that expeller-process coconut meal contains considerably more crude protein than yellow corn, with a constant protein level adjusted by lowering the tuna and soybean meals, but that the protein fraction does not provide the amounts of available lysine required by the birds for optimum growth and utilization. This also was the case in broiler studies A (starting period) and $\mathbf{C}$ (fattening period).

TABLE 5.-Rate of gain, utilization of feed by growing birds of a laying stock, and comparative feed costs of diets

\begin{tabular}{|c|c|c|c|c|c|c|c|}
\hline $\begin{array}{c}\text { Diet } \\
\text { number }\end{array}$ & $\begin{array}{l}\text { Percent } \\
\text { coconut- } \\
\text { protein }\end{array}$ & $\begin{array}{l}\text { Percent } \\
\text { lysine }\end{array}$ & $\begin{array}{c}\text { Percent } \\
\text { metbionine- } \\
\text { cystinel }^{1}\end{array}$ & $\underset{\substack{\text { Main nean net } \\
\text { grams }}}{\text { gram }}$ & $\begin{array}{c}\text { Average } \\
\text { cost/pound } \\
\text { of feed² } \\
\text { cents }\end{array}$ & $\begin{array}{c}\text { Mean } \\
\text { efficiencyzaz } \\
\text { feed/gain } \\
\text { ratio }\end{array}$ & $\begin{array}{c}\text { Feed } \\
\text { cost/pound } \\
\text { producedi } \\
\text { cents }\end{array}$ \\
\hline \multicolumn{8}{|c|}{ Study $F$} \\
\hline $\begin{array}{l}31 \\
32 \\
33 \\
34\end{array}$ & $\begin{array}{r}0.0-16.0 \\
18.5-18.4 \\
55.5-23.2 \\
74.2-25.6\end{array}$ & $\begin{array}{r}0.91 \\
.98 \\
1.05 \\
1.12\end{array}$ & $\begin{array}{r}0.61 \\
.65 \\
.69 \\
.73\end{array}$ & $\begin{array}{l}400 \mathrm{a} \\
404 \mathrm{a} \\
386 \mathrm{a} \\
418 \mathrm{a}\end{array}$ & $\begin{array}{l}5.06 \\
4.82 \\
4.35 \\
4.11\end{array}$ & $\begin{array}{l}7.42 \mathrm{a} \\
7.78 \mathrm{a} \\
8.63 \mathrm{a} \\
9.57 \mathrm{a}\end{array}$ & $\begin{array}{l}37.55 \\
37.50 \\
37.54 \\
39.33\end{array}$ \\
\hline \multicolumn{8}{|c|}{ Study G-Part I } \\
\hline $\begin{array}{l}35 \\
36 \\
37\end{array}$ & $\begin{array}{r}.0-16.0 \\
25.0-16.0 \\
50.0-16.0\end{array}$ & $\begin{array}{r}0.74 \\
.62 \\
.51\end{array}$ & $\begin{array}{r}0.57 \\
.53 \\
.49\end{array}$ & $\begin{array}{l}372 \text { a } \\
359 a \\
331 \text { a }\end{array}$ & $\begin{array}{l}4.93 \\
4.49 \\
4.02\end{array}$ & $\begin{array}{l}4.54 \mathrm{a} \\
4.94 \mathrm{a} \\
5.26 \mathrm{a}\end{array}$ & $\begin{array}{l}22.38 \\
22.18 \\
21.15\end{array}$ \\
\hline \multicolumn{6}{|c|}{ Study G-Part II } & \multicolumn{2}{|l|}{-} \\
\hline $\begin{array}{l}35 \\
38 \\
39\end{array}$ & $\begin{array}{r}.0-16.0 \\
25.0-19.0 \\
50.0-22.0\end{array}$ & $\begin{array}{r}0.74 \\
.82 \\
.89\end{array}$ & $\begin{array}{r}0.57 \\
.61 \\
.64\end{array}$ & $\begin{array}{l}372 a \\
390 a \\
372 a\end{array}$ & $\begin{array}{l}4.93 \\
4.62 \\
4.30\end{array}$ & $\begin{array}{l}4.54 \mathrm{a} \\
4.49 \mathrm{a} \\
4.78 \mathrm{a}\end{array}$ & $\begin{array}{l}22.38 \\
20.74 \\
20.55\end{array}$ \\
\hline
\end{tabular}

1 See 1 table 3.

$2,8,4$ See $2,8,4$ table 2 .

\section{SUMMARY}

The results of these studies demonstrate that: 1 , Coconut meal contains a high level of crude protein but is deficient in some of the essential amino acids, particularly lysine and methionine-cystine, required by poultry; 2 , a caloric deficiency resulted in practical-type diets when a per unit substitution by coconut meal was made of yellow corn; 3, levels of coconut meal (expeller-process) as high as 50 percent were used satisfactorily by broilers in properly-balanced, practical-type, fattening diets; and 4, economic considerations, such as price and availability of ingredients, will determine 
the amount of coconut meal to incorporate in practical-type poultry feeds up to the limiting level of $\mathbf{5 0}$ percent.

\section{RESUMEN}

Los resultados obtenidos en este estudio y aquí informados, con aves de lineas ponedoras y para asar en diferentes etapas de crecimiento, demuestran que: 1, Aunque la harina de coco contiene un alto porcentaje de proteína bruta, la misma es, sin embargo, deficiente en algunos de los aminoácidos esenciales requeridos por las aves, particularmente la lisina y la metionina-cistina; 2, la sustitución de unidad por unidad de harina de maíz por harina de coco resultó en una deficiencia en calorías en las dietas prácticas; 3, la harina de coco (elaborada por el proceso "expeller") fue consumida satisfactoriamente por aves para asar, en dietas prácticas para el engorde, a un nivel de hasta 50 por ciento; y 4, las consideraciones económicas tales como el precio y la disponibilidad de los ingredientes determinarán el nivel de harina de coco que deberá usarse en dietas prácticas, hasta un nivel máximo de 50 por ciento.

\section{LITERATURE CITED}

1. Official Methods of Analysis of the Association of Official Agricultural Chemists, 10th ed., Washington, D.C., 1965.

2. Bose, R. C., Clatworthy, W. H., and Shrikhande, S. S., Tables of partially balanced designs with two associate classes, N. C. Agr. Exp. Sta. Tech. Bull. 107, 1954.

3. Castillo, L. S., Gloria, L. A., Gerbacio, A. L., Gatapia, A. R., Aglibut, F. B., and Macam, B. T., High levels of copra meal in poultry and livestock rations, II. Influence of age of chicks on its utilization, Phillippine Agr. 48: 381-98, 1965.

4. Fronda, F. M., Katigbak, T. V., and Ortigas, R. Z., Solvent-process extracted copra meal versus expeller-process extracted copra meal in poultry rations, Philippine Agr. 41: 314-8, 1958.

5. Momoñgan, V. G., Castillo, L. S., Gatapia, A. R., and Resurrección, R. S., High levels of copra meal in poultry and livestock rations, I. Methionine and lysine supplementation in broiler rations, Philippine Agr. 48: 163-80, 1964.

6. National Research Council, Joint United States-Canadian Tables of Feed Composition, Pub. 1232, 1964.

7. - Nutrient requirements of poultry, Pub. 1345, 1965.

8. Snedecor, G. W., Statistical Methods, The Iowa State College Press, Ames, Iowa 1959.

9. Soldevila, M., Amino acid content and nutritive value of tuna (Thunnus sp.) fishmeals relative to their crude protein content, J. Agr. Univ. P.R. 54 (3:) 582-4.

10. Thomas, O. A., and Scott, M. L., Coconut oil meal as a protein supplement in practical poultry diets, Poultry Sci. 41: 477-85, 1962.

11. Zelem, M., The analysis of covariance for incomplete block designs, Biometrics 18: 309, 1957. 